ENTREPRENEURSHIP AND SUSTAINABILITY ISSUES

ISSN 2345-0282 (online) http://jssidoi.org/jesi/

2020 Volume 8 Number 2 (December)

http://doi.org/10.9770/jesi.2020.8.2(40)
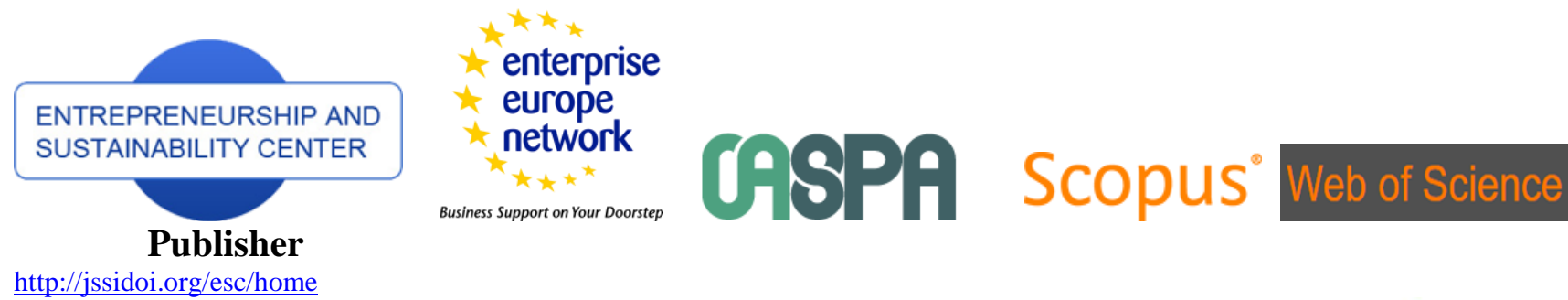

http://jssidoi.org/esc/home

Business Support on Your Doorstep

\title{
ENTREPRENEURSHIP SUPPORT WAYS AFTER THE COVID-19 CRISIS*
}

\author{
Manuel Chaves-Maza ${ }^{1}$, Eugenio M. Fedriani Martel ${ }^{2}$ \\ ${ }^{1,2}$ Pablo de Olavide University, Crta. Utrera Km.1 41014, Sevilla, Spain \\ E-mails: ${ }^{1} \underline{\text { mchaves@upo.es }} ;{ }^{2}$ efedmar@upo.es
}

Received 20 March 2020; accepted 11 September 2020; published 30 December 2020

\begin{abstract}
The impact of the Covid-19 on Europe economy has been similar to that produced in the 2008 crisis, even with worse long-term consequences. Most governments have implemented recovery plans similar to those that were then implemented. However, there are differences in the economic impact that require different methodologies which focus on the microenvironment. Entrepreneurs' sponsorship may help to recover the current socio-economic situation. Simultaneously, technological progress in Artificial Intelligence and Big Data allows the analysis of vast amounts of information and support decision making. This paper shows a brief introduction of entrepreneurship policy in twenty countries after the irruption of the Covid-19 to contextualize, and applies Artificial Intelligence to examine factors whose influence is strong in the survival rate of entrepreneurs within a public support program. Specifically, two types of artificial networks are used: self-organizing maps and multilayer perceptron (respectively, SOM and MLP). After the application of neural networks on a data set of 2,221 entrepreneurs from Andalusia (Spain) and with 769 variables taken during the recovery after the crisis from 2008 to 2012, the prediction in the probability of entrepreneurial survival and business success is shown to be realistic in more than $98 \%$ of individuals analysed.
\end{abstract}

Keywords: entrepreneurship; sponsorship; artificial neural networks (ANN); self-organizing maps (SOM); multilayer perceptron (MLP)

Reference to this paper should be made as follows: Chaves-Maza, M., Fedriani Martel, E.M. 2020. Entrepreneurship support ways after the Covid-19 crisis. Entrepreneurship and Sustainability Issues, 8(2), 662-681. http://doi.org/10.9770/jesi.2020.8.2(40)

JEL Classifications: L26, L38, Q01

\section{Introduction}

The policies carried out in the first half of 2020 and proposed by the governments for the recovery of the economy have been very different if we look at the countries of the European Union and associated with it. After the arrival of the first case of Coronavirus in Europe on January 24 (Rothe et al., 2020) and the first reactions to

\footnotetext{
* This research was supported by Pablo de Olavide University (Spain) and data was collected from Andalucia Emprende Fundation that participates in the European Erasmus for Young Entrepreneurs project through the project called MOVE YE
} 
ENTREPRENEURSHIP AND SUSTAINABILITY ISSUES

ISSN 2345-0282 (online) http://jssidoi.org/jesi/

2020 Volume 8 Number 2 (December)

http://doi.org/10.9770/jesi.2020.8.2(40)

Make your research more visible, join the Twitter account of ENTREPRENEURSHIP AND SUSTAINABILITY ISSUES: @Entrepr69728810

control the spread of the disease, in such countries as France, Spain or Italy there has been one of the biggest falls in the economy in recent times, the rest of the reports followed world levels like USA or UK. The International Monetary Fund (IMF) now foresees a global recession of 3\% in 2020 and a rebound of 5.8\% in 2021. Still each month of confinement and isolation expansion has a direct impact on the economy and entrepreneurs in all these countries. However, if we compare this crisis with that of 2008, there is one issue worth noting: the speed and magnitude of the response from central banks and governments. Table 1 shows the distribution of total cases by country, the number of recovered, active cases and deaths, showing how it has affected some of the leading economies worldwide. Within a few weeks of the crisis, except for Russia and Turkey, most of the nine emerging economies in Central and Eastern Europe have already requested emergency assistance from the IMF. Italy and Spain, the third and fourth economies in the eurozone, were practically paralyzed as the two countries most affected by the pandemic; and other large economies such as Germany and France have applied severe restrictions on movement and activity.

Table 1. First countries affected by coronavirus according to data from May 17 2020, ordered by the number of deaths.

\begin{tabular}{lrrrrrrr}
\hline $\begin{array}{l}\text { Country, } \\
\text { Other }\end{array}$ & \multicolumn{1}{l}{$\begin{array}{l}\text { Total } \\
\text { Cases }\end{array}$} & \multicolumn{1}{l}{$\begin{array}{l}\text { Total } \\
\text { Deaths }\end{array}$} & $\begin{array}{l}\text { Total } \\
\text { Recovered }\end{array}$ & $\begin{array}{l}\text { Active } \\
\text { Cases }\end{array}$ & $\begin{array}{l}\text { Serious, } \\
\text { Critical }\end{array}$ & $\begin{array}{l}\text { Tot Cases/ } \\
\text { 1M pop }\end{array}$ & $\begin{array}{c}\text { Deaths/ } \\
\text { 1M pop }\end{array}$ \\
\hline World & $4,750,403$ & 313,805 & $1,830,514$ & $2,606,084$ & 44,796 & 609 \\
$\underline{\text { USA }}$ & $1,509,422$ & 90,142 & 339,572 & $1,079,708$ & 16,248 & 4,563 \\
$\underline{\text { UK }}$ & 240,161 & 34,466 & N/A & N/A & 1,559 & 3,54 & 508 \\
$\underline{\text { Italy }}$ & 224,76 & 31,763 & 122,81 & 70,187 & 775 & 3,717 & 525 \\
$\underline{\text { Spain }}$ & 277,719 & 27,65 & 195,945 & 54,124 & 1,152 & 5,94 & 591 \\
$\underline{\text { France }}$ & 179,365 & 27,625 & 61,066 & 90,674 & 2,132 & 2,749 \\
$\underline{\text { Brazil }}$ & 233,511 & 15,662 & 89,672 & 128,177 & 8,318 & 1,1 \\
Belgium & 55,28 & 9,052 & 14,63 & 31,598 & 371 & 4,772 \\
$\underline{\text { Germany }}$ & 176,45 & 8,027 & 153,4 & 15,023 & 1,203 & 2,107 \\
$\underline{\text { Iran }}$ & 120,198 & 6,988 & 94,464 & 18,746 & 2,705 & 1,433 \\
$\underline{\text { Netherlands }}$ & 43,995 & 5,68 & N/A & N/A & 346 & 2,568
\end{tabular}

Source: https://www.worldometers.info/coronavirus/ N/A: Not available.

Although we can draw a parallel between the financial crisis of 2008 and the health crisis of 2020, there are some characteristics of the latter that differentiate it and frame its peculiarities (Barcena, 2020):

- The world is facing unprecedented health and humanitarian crisis in the last century in an adverse economic context. Unlike the last financial crisis, this is not a financial crisis but of people, health and wellness.

- A war economy situation is indispensable for the role of the state and not the market, therefore the states are taking a central role in suppressing the virus and the risks that will affect the economy and social cohesion.

- Flattening the contagion curve requires measures that reduce interpersonal contacts and will generate economic contraction, will paralyze productive activities and destroy aggregate / sectoral demand.

- How not to flatten the economy: strict and effective compliance with quarantines and health measures public will be the most efficient and fastest way to reduce economic costs.

- International cooperation: the way out of the crisis will depend on the economic strength of each country, so therefore, given the asymmetries between developed and developing countries, the role of the UN, the 
Make your research more visible, join the Twitter account of ENTREPRENEURSHIP AND SUSTAINABILITY ISSUES: @Entrepr69728810

IMF and the The World Bank will be essential to guarantee access to financing, sustain social spending and maintain economic activity with innovative measures ("out of the box").

There are many channels through which an infectious disease outbreak influences the economy. How it affects micro, small and medium-sized companies are given by the perceived opportunities that are one of the aspects that most affect entrepreneurs and entrepreneurs, as happened after the 2008 crisis, where practically all countries saw they saw affected. As can be seen in Figure 1, Spain and Italy lost a good part of that positive perception, which was not recovered until practically six years later. In other economic powers such as the United Kingdom and the USA. This recovery was faster. However, dependence on the giant has increased since that date and there is a rise in China's importance in the world economy today (McKibbin \& Fernando, 2020).

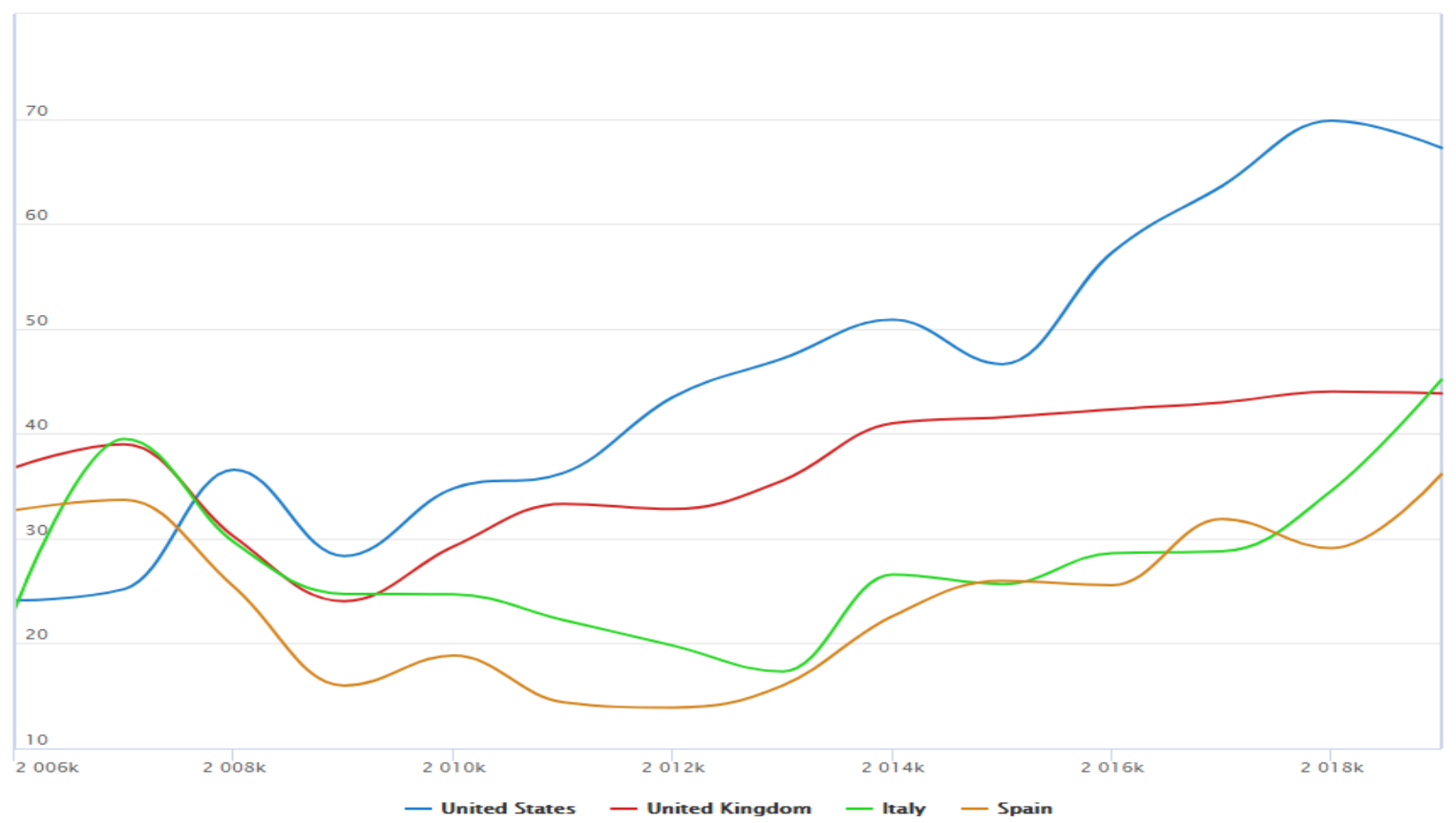

Fig. 1. Perceived opportunities. Percentage of 18-64 population who see good opportunities to start a firm in the area where they live. Source: National Expert Survey of GEM Monitor database and own elaboration.

Even though that numerous mechanisms have been implemented to guarantee the sustainability of companies and avoid serial bankruptcies, the impact on turnover and profits will not be less violent. Returning to normal will take time. Thus, while equity valuations may appear attractive at these levels, they will undoubtedly not be sufficient to fuel a sustained increase, given the weak outlook for activity.

Having regional governance, with criteria of the geography of health, with discussions to reach colective agreements, are unavoidable pillars in a hyper-connected world. The lack of union, agreed on standards and intertwined health policies further weaken the weakness of the situation, and we know that a diseased body is an easy prey for any storm, be it COVID-19 or other (DiGiacomo, 2020). That's why most of the world's governments have sought support from the political forces and citizens to be able to carry out decisions that affect our life and activity as we knew it until then. 
ENTREPRENEURSHIP AND SUSTAINABILITY ISSUES

ISSN 2345-0282 (online) http://jssidoi.org/jesi/

2020 Volume 8 Number 2 (December)

http://doi.org/10.9770/jesi.2020.8.2(40)

Make your research more visible, join the Twitter account of ENTREPRENEURSHIP AND SUSTAINABILITY ISSUES: @Entrepr69728810

Analyzing Figure 2 from National Expert Survey GEM Monitor database (Gem, 2020), there was a cyclical evolution that happened to the indicators of openness of the internal market, support and government policies, the financing of entrepreneurs, the bureaucracy and rates, and government support programs. It is observed that the decline after the crisis 2008 was widespread in the leading countries that have been affected by the Covid-19 crisis, taking up to 8 years on some indicators to return to 2006 rates. Due to the parallelism of both crises, and given that according to many of the sources consulted indicate the deepest depth of this health crisis, governments around the world must prepare to rebuild this set of indicators and strengthen their economy by supporting the entrepreneurship environment.

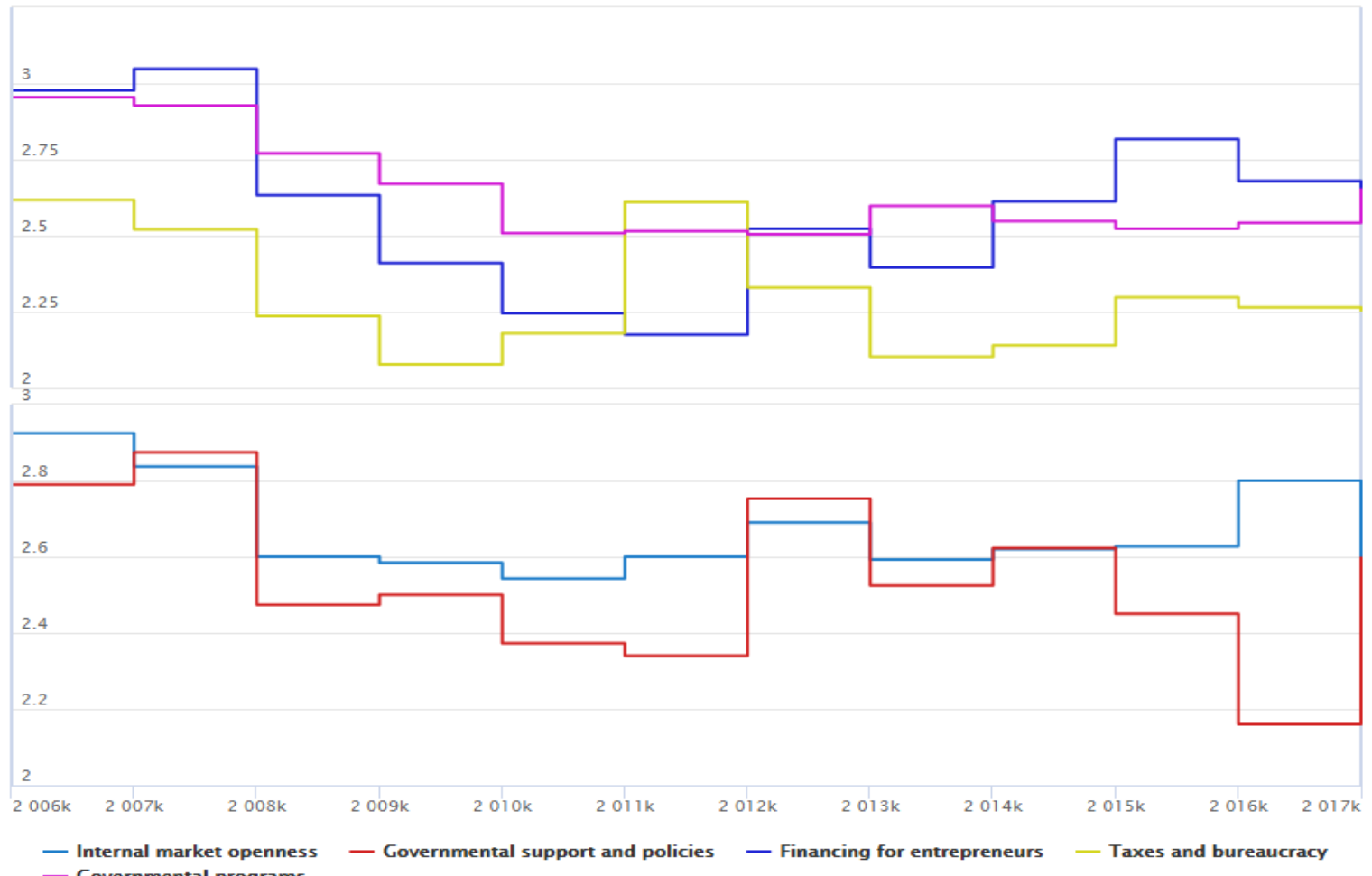

Fig. 2. Evolution of mean of entrepreneurship indicators: Internal market openness, Governmental support and policies, financing for entrepreneurs, taxes and bureaucracy and governmental programs of the ten more affected countries in the Covid-19 crisis (USA, Spain, Italy, UK, France, Germany, Brazil, Iran, Belgium and Netherlands).

Source: National Expert Survey of GEM Monitor data base and own elaboration. ${ }^{\dagger}$

If we look at the preceding context in which the pandemic occurs, we see that it was not as favorable as we might think either. Young people have been hit in recent times by the crisis in a very significant way. Labor market conditions have changed, and they feel confused. There are guidance, counseling and support services for entrepreneurs. Still, they are not sure about the best way to help them. Despite the large amount of information

\footnotetext{
$\dagger$ Financing for entrepreneurs: The availability of financial resources "equity and debt" for small and medium enterprises (SMEs). Governmental support and policies: The extent to which public policies support entrepreneurship - entrepreneurship as a relevant economic issue. Taxes and bureaucracy: The extent to which public policies support entrepreneurship - taxes or regulations are either size-neutral or encourage new and SMEs. Governmental programs: The presence and quality of programs directly assisting SMEs at all levels of government (national, regional, municipal). Internal market openness: The extent to which new firms are free to enter existing markets
} 


\section{ENTREPRENEURSHIP AND SUSTAINABILITY ISSUES}

ISSN 2345-0282 (online) http://jssidoi.org/jesi/

2020 Volume 8 Number 2 (December)

http://doi.org/10.9770/jesi.2020.8.2(40)

Make your research more visible, join the Twitter account of ENTREPRENEURSHIP AND SUSTAINABILITY ISSUES: @Entrepr69728810

they have, they do not know which factors are positive and which are hamful, what effects will imply the inmediate decisions, what probability of success is hidden in each business sector, etc. As an alternative, often overly generalist training is imposed, in which very diverse contents are transmitted (Azizi and Mahmoudi, 2019; Sörensson and Bogren, 2019).

In this context, institutional support is considered essential. Concerning guidance to entrepreneurs, the importance of the intention to undertake is undoubted (Mamun, Che Nawi, Mohiuddin, Shamsudin and Fazal, 2017) and this fact makes it easier for entrepreneurs to be willing to receive training and prior support. However, it is not so clear that the other relevant factors can be taught to young people: first, because entrepreneurs cannot be oriented in one same way with different characteristics and different business ideas; second, because it is not well-known what leads to success in each case.

In this study, it is intended to combine one of the most critical crises suffered by humanity in recent decades with the use of the latest data analysis techniques since we are in the information age. The previous questions suggest the use of sophisticated tools, perhaps supported by Artificial Intelligence. Still, first it is convenient to ask if a computer program will be able to correctly guide an entrepreneur (or, at least, if computer science can help in this task to a support service for entrepreneurs). That's why it is necessary to develop a way to predict the success or survival of entrepreneurs based on the information available before starting the business venture. Once the probability of success is known in each case, it is possible to modify some of the input variables (maybe several times) and assess which is the best option for each entrepreneur.

Nowadays, the essential ingredients to enable the use of technology are already present: sufficient information, updated and validated, useful software for training artificial neural networks, entities (unusually public) interested in improving support services (Urban, 2019), etc. It remains unproven that the Artificial Intelligence-based methodologies are well-founded to solve this global problem.

Thus, the main objective of this paper is twofold: to verify if it is possible to use artificial intelligence to predict the success of entrepreneurs and to train an artificial neural network to do so, and use it in this context of world crisis caused by Covid-19.

Attend to the differences that have been observed in this current crisis concerning 2008 one, the new role for the state should be more stronger and supports those most affected which are micro, small and medium-sized enterprises that facilitate the development of the economy in which the International cooperation and interaction is limited. It is required not to fall into the errors that have been detected in the recovery from previous crises and to take advantage of all historical information to guide more efficiently and effectively entrepreneurs who intend to restore business models in this new environment. That's why, in the following sections, a brief analysis of the literature will be carried out to observe what factors to consider, and methodological review of artificial intelligence as SOM and MLP to build a success prediction model that allows a better performance of sponsorship in the reconstruction of the global economy.

\subsection{Literature background}

The entrepreneurial orientation can be understood as a set of processes and practices related to the decision making that enable the activity of both individuals and companies, which is an aspect that is positively associated with to profitability and growth of projects (Covin \& Slevin, 1991; Ireland, Covin and Kuratko 2009; Wiklund \& Shepherd 2005; Cuevas-Vargas, Parga-Montoya and Fernández-Escobedo, 2019). 


\section{ENTREPRENEURSHIP AND SUSTAINABILITY ISSUES}

ISSN 2345-0282 (online) http://jssidoi.org/jesi/

2020 Volume 8 Number 2 (December)

http://doi.org/10.9770/jesi.2020.8.2(40)

Make your research more visible, join the Twitter account of ENTREPRENEURSHIP AND SUSTAINABILITY ISSUES: @Entrepr69728810

If we analyze the set of capacities and qualities that define the entrepreneur, there are some of them linked to his attitude and the way of facing risk, reflecting his/her psychological and social profile (Al-Jubari, 2019). Although we try to reduce this risk, there are many other characteristics that maintain all their importance. According to the literature, these most relevant characteristics are the following: negotiating and commercial attitude (Douglas \& Judge, 2001); ambition (Larrea \& Ayerbe, 1996); positive mental attitude (Timmons \& Spinelli, 1994); creativity (Hawkins \& Turla, 1987); decision (Álvarez \& Busenitz, 2001); social skills (Baron, 2000); initiative (Moskvina, 2013; Gibb, 1993); leadership (Anzola, 1997); planning (Sandberg, Robinson and Pearce, 2001; Stewart and Roth, 2001); tenacity (Rock, 1987); vision of the future (Filella, 1997). All these factors undoubtedly influence the success of the business project.

To carry out the present investigation, all factors that increase the sustainable competitive advantages of entrepreneurs (and, therefore, are key to their survival and growth) must be identified. Although there is no consensus on the definition of key concepts in entrepreneurship, the Theory of Resources and Capabilities maintains that the resources of the company influence the performance and organizational results, so that companies that have resources of superior quality will have greater benefits and greater possibilities of achieving sustainable competitive advantages (Peteraf, 1993). This idea provides an excellentclue to locate the most appropriate variables to measure the critical factors of entrepreneurship in each of the four classic approaches:

i. Within the "individual" approach, the prevailing variables are eare education, previous experience, intentions of the entrepreneur, entrepreneur attitude and age.

ii. In the "environment" approach: growth; structure; dynamism.

iii. In the "organization" approach: prior planning; social capital.

iv. In the "process" approach: focus and differentiation strategy; marketing ability.

In any case, to give a broader idea of what the existing literature contemplates and to justify the subsequent appearance of a complex model, next we list some factors that could be measured by other variables and that have also been considered critical factors in the business success, according to the literature (Mitchelmore and Rowley, 2010):

- Entrepreneurial skills: identification and definition of a viable market niche; development of appropriate products or services for companies to choose the market niche or product innovation; generation of the idea; surrounding analysis; recognize and envision taking advantage of opportunities; formulate strategies to take advantage of opportunities.

- Business and management skills: development of the management system necessary for the long-term functioning of the organization; acquisition and development of resources required by the company to operate; operational skills for business; previous involvement in the creation of other companies; managerial experience; familiarity with the industry; financial and budgeting skills; previous experience; direction style; marketing skills; technical skills; necessary skills in the industry; ability to implement the strategy (program development, budgets, procedures, performance evaluation); familiarity with the market; preparation of business plans; ability to achieve objectives; managerial skills.

- Competencies of personal relationships: development of the organizational culture necessary to guide the company; ability to delegate; ability to motivate other individuals and groups; hiring skills; skills for maintaining personal relationships; leadership skills.

- Conceptual and relationship competencies: conceptual competencies; organizational skills; interpersonal skills; skills to direct clients; ability to manage clients; mental capacity to coordinate activities; skills for written 
ENTREPRENEURSHIP AND SUSTAINABILITY ISSUES

ISSN 2345-0282 (online) http://jssidoi.org/jesi/

2020 Volume 8 Number 2 (December)

http://doi.org/10.9770/jesi.2020.8.2(40)

Make your research more visible, join the Twitter account of ENTREPRENEURSHIP AND SUSTAINABILITY ISSUES: @Entrepr69728810

communication; skills for oral communication; skills for decision making; skills for analysis; skills for logical thinking; negotiation skills; commitment capacity.

Despite the many variables of the previous lists, the characteristics of the entrepreneurs and their projects are not sufficient to predict business success. The environment not only affects the motivation of entrepreneurs and the generation of projects but also modulates the validity of the factors mentioned above: aspects that may be very relevant in an environment may not be significant in a different one. However, it is rarely possible to influence the environment, except through orientation and support for entrepreneurs. This research aims to justify that it is possible to estimate what will be the future result of an entrepreneur and use that estimate to optimize the processes of training, guidance and support.

\subsection{Structure of the paper}

Firstly, the data collection from the different available sources of information is explained, highlighting the database of the "Andalucía Emprende" Foundation. Several usual multivariate analysis methodologies are applied to these data, which serve to select the main variables that have a direct influence on the final variables that are to be optimized.

Secondly, the SOM methodology is applied to the data and the selected variables, grouping the cases according to their similarity in the set of variables studied. The groups obtained are analyzed and their relationship with the output variables is reviewed so that the profile of the entrepreneurs of each group can be characterized according to their probability of success, survival or failure. These groups are the basis for the efficient prediction of any probability since it requires a classification based on the a priori variables that are consistent with the variables (survival or success) that we want to estimate.

Thirdly, a MLP is trained and used to predict entrepreneurs' success. And finally, we reflect on how the results obtained can be useful to improve the probability of survival and success, based on the advice, the suggested training complements and the different types of public support offered.

\section{Sample and methodology}

The sample comes from the database of the "Andalucía Emprende" Foundation (AEF), which collects data on entrepreneurs from 1998. This information is taken in one of the regions with the most barriers and obstacles to entrepreneurship, during the time of the crisis from 2006 and recovery until 2013, which will help us to project the SOM and MPL models. The main descriptive statistics of this database can be found at "Relevant factors to optimize public services to support entrepreneurs and the survival rate of companies" (Chaves \& Fedriani, 2018). The information it contains has been complemented by other databases of public access that are detailed below and that make it possible for the analysis to have a total of 769 explanatory variables:

- Data base from "Andalucía Emprende" Foundation: 238 variables of entrepreneurs. This research was supported by Pablo de Olavide University (Spain) and data was collected from this Foundation that participates in the European Erasmus for Young Entrepreneurs project through the project called MOVE YE.

- To consider the environment where the entrepreneur is located: 325 variables from the Institute of Statistics and Cartography of Andalusia (https://www.juntadeandalucia.es/institutodeestadisticaycartografia ); 125 variables from the National Statistics Institute (https://www.ine.es/ ); 15 variables from the Cadastral Electronic Site (https://www.sedecatastro.gob.es ). 


\section{ENTREPRENEURSHIP AND SUSTAINABILITY ISSUES}

ISSN 2345-0282 (online) http://jssidoi.org/jesi/

2020 Volume 8 Number 2 (December)

http://doi.org/10.9770/jesi.2020.8.2(40)

Make your research more visible, join the Twitter account of ENTREPRENEURSHIP AND SUSTAINABILITY ISSUES: @Entrepr69728810

- To consider the segment where the entrepreneur performs his activity: 250 variables from SABI Company Database (https://sabi.bvdinfo.com/ip/); 25 variables from Statistics of Foreign Trade (http://datacomex.comercio.es/); 16 variables from Statistics from the Central Mercantile Register (http://www.rmc.es/estadisticas/EstadisticaSocietaria.aspx ).

The variables mentioned above have been classified into three groups, according to Schnabl (2010). Of these variables, the main ones that have been used for the design of neural networks are highlighted below, after performing the first screen according to their significance:

(1) Descriptive variables of the entrepreneur and the project: the level of studies of the entrepreneur before the start-up of the project (if there are several promoters, the mean is calculated); the legal form of the new company; type of activity carried out by the company; the investment planned in the budget presented within the business plan; the funding provided in the budget; the level of studies (if there are several promoters, the maximum is calculated); the age of the promoter(if there is more than one promoter, the average value is calculated); the number of full-time employees with whom the business project starts.

(2) Environment variables and public support: the contractual relationship with the "Andalucía Emprende" Foundation (classified as "incubation" or "pre-incubation"); the type of accommodation (office, warehouse or "no accommodation provided"); the incentives for creation or innovation (dichotomous variable); the number of support services received in the first three months of activity; the financial profitability of the environment; participation in a program to revitalize the local productive fabric (dichotomous variable); the economic indicator of the environment (aggregate index on the business fabric of the municipality in which the entrepreneur is located); if there is a forecast of employment that is generated by the entrepreneur within the business plan presented (dichotomous variable).

(3) Dependent variables and other variables linked to the interpretation of the model: business success (if it meets the objective defined at the beginning of its activity); failure (its survival is less than two years after its creation); the average value of added indefinite workers; the average value of added temporary workers; average billing of the project; the ratio between billing and project employees; relative financial profitability concerning companies in the sector; total investments made. About survival time, we must consider that there are cases of companies that meet short-term objectives of less than one year, in which case they would not fall within this denomination and would have to be analyzed separately (Morris, Schindehutte and Allen 2005; George \& Bock 2011; Bruneel, Spithoven and Clarysse 2017).

In particular, the dependent variables in this third item are incorporated in order to have different ways to infer if each entrepreneur has achieved his initial objectives.

The techniques applied in this paper can be classified into two main groups located in the two corresponding phases of the study. First, multivariate analysis is used to select the relevant variables. Since the database has a large number of variables for each business project, it is convenient to distinguish between those variables that are significant and those that are not relevant for the type of research that is intended to be carried out. Subsequently, two different types of artificial neural networks are applied. The SOM technique is responsible for the unsupervised classification within the group of possible cases; this classification is essential to be able to predict later the probability of success, failure and survival of each individual because such estimation would only be useful if the groups generated on the basis of the "independent" variables behaved in a homogeneous way with respect to the "dependent" variables. Finally, with the aid of the definition of success, a MLP estimates the probability of success from the initial variables. The main tools used in this study, the neural networks (SOM and MLP), are described below. 


\section{ENTREPRENEURSHIP AND SUSTAINABILITY ISSUES}

ISSN 2345-0282 (online) http://jssidoi.org/jesi/

2020 Volume 8 Number 2 (December)

http://doi.org/10.9770/jesi.2020.8.2(40)

Make your research more visible, join the Twitter account of ENTREPRENEURSHIP AND SUSTAINABILITY ISSUES: @Entrepr69728810

\section{SOM technique}

Unlike the networks with supervised training (like MLP), the classification of the cases by SOM is carried out autonomously (without requiring the participation of the researcher), discovering common characteristics among the instances, regularities, correlations as well as categories in the input data.

Accurately, the SOM analysis of the data has been carried out to obtaining a first unforced classification of homogeneous groups that can serve to understand the behavior of entrepreneurs better and to justify the viability of using supervised neural networks for classification, simulation, adjustment and estimation. For the calculations, the "Kohonen" package of the R program was used, with a grid of 10x10, with several iterations of 500, with an Alpha learning rate of 0.05 to 0.01 and with 100 neurons. The SOM model was designed based on the set of all the prior descriptive variables, previously using classical multivariate techniques for the selection of variables. Among the methods used, the following stand out: (i) cluster analysis; (ii) factor analysis; (iii) logit analysis; (iv) structural equation models; (v) decision trees (Mangiameli, Chen and West, 1996).

Let us contextualize the technique used (SOM). It was developed in 1982, thanks to pieces of evidence discovered at the brain level by T. Kohonen. A SOM is an artificial neural network composed of two layers where a competition of neurons of the output layer takes place. This type of model is an unsupervised network because there is no external expert that indicates whether the neural network is operating correctly or incorrectly; this is consistent with the fact that no measurable output is available to which the neural network should tend. Consequently, in the training phase not only the weights of the winning neuron are updated but also the weights of neighboring neurons are modified, for which a neighborhood function is defined: $f\left(i, i^{*}\right)$, where $i^{*}$ is the socalled "winner neuron" (Lamedica et al., 1996).

The goal of a SOM is to discover common characteristics, regularities, correlations as well as categories in the input data. The feature space is based on the physical disposition of the output neurons to model some of the characteristics of the input space. It is said, therefore, that the neurons must self-organize according to the stimuli (data) coming from the outside. In this sense, with the usual notation, if two inputs, $\mathrm{x}_{1}$ and $\mathrm{x}_{2}$, are close to each other concerning some measure in the input space and cause the activation of the output neurons, then $\mathrm{y}_{\mathrm{a}}$ and $\mathrm{y}_{\mathrm{b}}$ must be close to each other with respect to some type of composition or disposition of the output neurons (CurielMarín, Passoni, Olmedo-Moreno and Fernández-Cano, 2018).

Due to the final two-dimensional output, the SOM can be understood as a projection from a high-dimensional data space to a two-dimensional graph of neurons. The most common topologies of this type of network are rectangular and hexagonal (Aparanji, Wali and Aparna 2018), being the latter the one used in this work.

The proposed SOM method is divided here into two fundamental phases. First, a prototype is selected as the winner of a competition between all of them and then the winning prototype is moved to better represent the points that belong to it. In the first phase, a distance between the prototypes and a point of the set of examples is calculated. For the calculation of this value, distance measures such as, for example, the Euclidean distance can be used. Then the prototype approaches following the learning equations.

\section{Supervised learning: MLP}

The history of the MLP is, if possible, better known than that of SOMs because its origin is in the simple perceptron, with which it can be said that the theory of artificial neural networks began. In the 1960s, the problems that the simple perceptron had were evident, but it was not until 1986 when Rumelhart and other authors improved the training system of the first artificial neural networks to allow their use with more than one hidden layer. 


\section{ENTREPRENEURSHIP AND SUSTAINABILITY ISSUES}

ISSN 2345-0282 (online) http://jssidoi.org/jesi/

2020 Volume 8 Number 2 (December)

http://doi.org/10.9770/jesi.2020.8.2(40)

Make your research more visible, join the Twitter account of ENTREPRENEURSHIP AND SUSTAINABILITY ISSUES: @Entrepr69728810

A MLP is a neural network that trains similarly to the human brain: by trial and error. When designing an MLP, the number of layers and the number of neurons per layer are determined. One can also determine the type of neuron activation function and the training procedure. Each edge or arch (which connects two neurons of consecutive layers) has a weight, which can be initially set but will change with training. Broadly speaking, the training of a MLP consists in presenting to the system some patterns (or particular cases) of which the result is known. If the network is right in its forecast on a case, its weights are not modified (i.e. the network "does not learn"). If the network fails to forecast, its weights will be modified to get closer to the desired result. When this process has been repeated enough times, the network is considered to have been trained.

To prevent that the learning of the data (overtraining), the data set is usually divided into two or more pieces: one is used for training and others to validate if the network also works with other data set (different from those used to train).

In general, the MLP fits much better than classical multivariate analysis, but it is often difficult to interpret the model generated by artificial intelligence. Anyway, once the neural network is trained, it is proposed to analyze the model obtained to deduce information about the factors that influence survival, which would allow, for example, in our case, to find out how to optimize the support service.

The MLP we use is a multilayer perceptron, two-layer feedforward model enhancement. The first layer with 84 neurons and the second with 3 , with a minimum training accuracy of $90 \%$. In our case, two different procedures have been used to train the two-layer MLP.

The first training was done with the SPSS software. Here, $70 \%$ of the data was used for network training, $10 \%$ for validation and the remaining $20 \%$ for testing. Obviously, due to the stochastic nature of the training process, every time it is repeated, slightly different results appear (although all of them may be similar). This also occurs if another MLP is designed or other software is used to train.

Second, a model improvement MLP has been used. The combination rule used for categorical variables is voting and the number of component models for self-increase and aggregation is 10.

Self-documenting aggregation produces replications of the training data set by sampling with the repetition of the original data set. Create bootstrap samples of equal size to the original data set. That is, a "component model" is created from each replication. Together, these component models form an assembly model. The set model scores some records with a combination rule; the available rules depend on the level of measurement of the destination.

The program used for this other training has been the IBM modeler. The method generates a set model through self-document aggregation, which generates several models to obtain more reliable predictions. It may take longer to generate and score sets than a standard model.

\section{Results and discussion}

A database of 769 variables was considered and, before the SOM analysis, a reduction in the number of variables was made through association analysis, a factorial study and other multivariate techniques, which allow us to identify which variables best explain the variable dependent within each category: descriptive variables of the entrepreneur and the project and environment variables and public support. Once a selection of 72 variables has been obtained, the SOM training is carried out. 
Make your research more visible, join the Twitter account of ENTREPRENEURSHIP AND SUSTAINABILITY ISSUES: @Entrepr69728810

Figure 3 shows the process of iterations in the SOM training. The average distance from each node to the nearby units shows, through the iterations, the expected progressive descent.

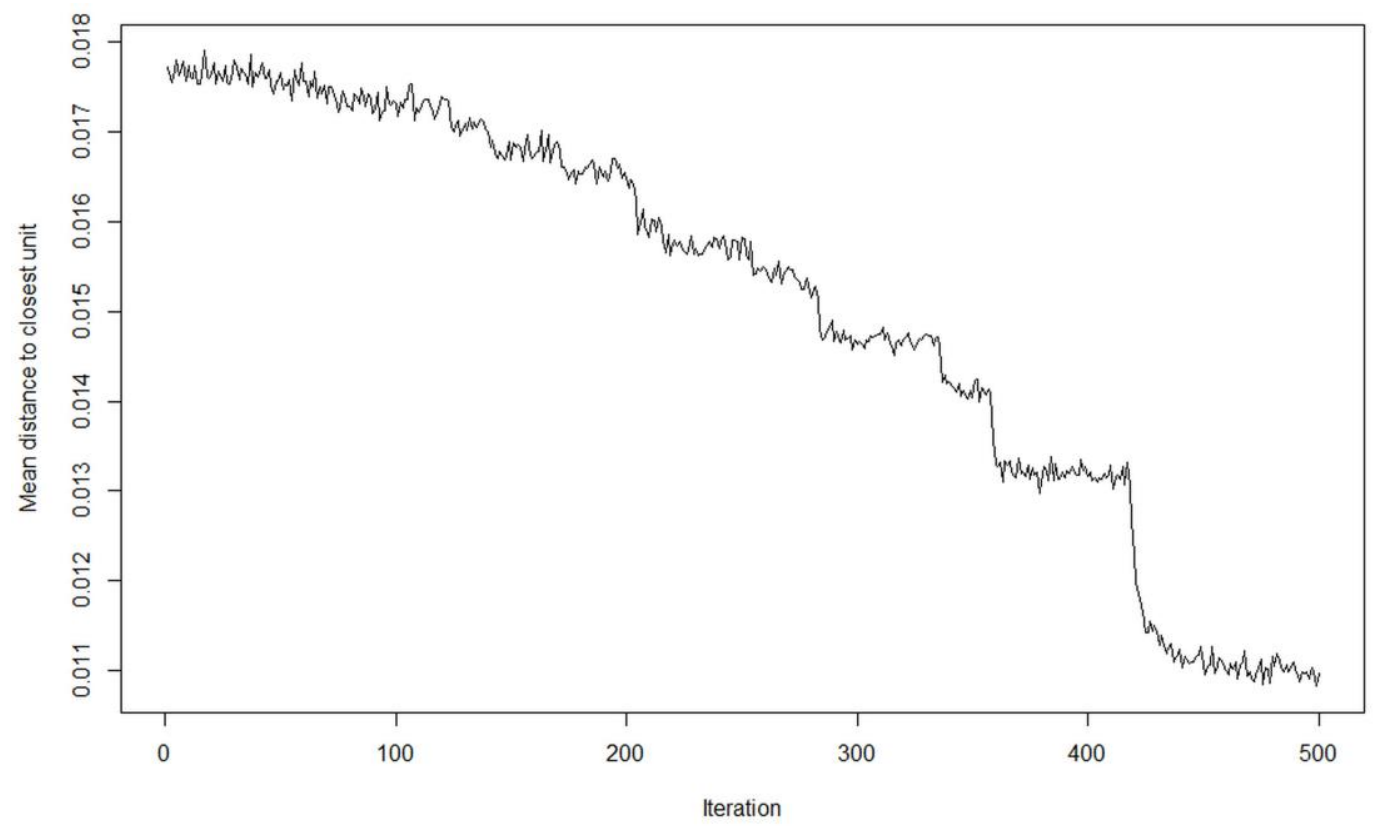

Fig. 3. The training process of the ANN. Source own elaboration Source: own elaboration from AEF database.

If we look at the general distance map (Figure 4), where the distances between the nodes are shown, some differentiated zones can be seen. In general, the presence of nodes with a considerable distance means that there are very differentiated nodes that, therefore, will be more likely to belong to different groups.

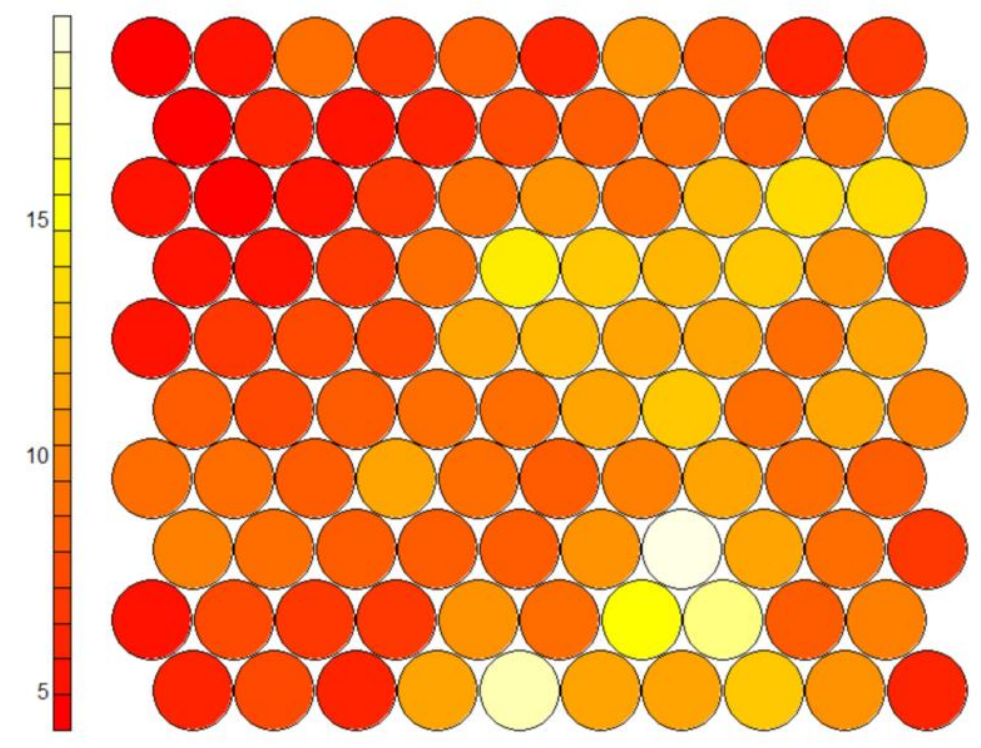

Fig. 4. Graph of SOM distances. Source own elaboration Source: own elaboration from AEF database. 


\section{ENTREPRENEURSHIP AND SUSTAINABILITY ISSUES}

ISSN 2345-0282 (online) http://jssidoi.org/jesi/

2020 Volume 8 Number 2 (December)

http://doi.org/10.9770/jesi.2020.8.2(40)

Make your research more visible, join the Twitter account of ENTREPRENEURSHIP AND SUSTAINABILITY ISSUES: @Entrepr69728810

Figure 5 shows the values in each of the variables that have been used to train the network, although in this case it is not shown with the classic radial format but in a linear manner, because of the high number of variables. Note that nodes with a similar silhouette (which implies even values in the different variables), are within the same classification (that is, in the same group or "cluster"). For the conformation of the clusters the function "add.cluster" has been used within the R program available in the Kohonen statistical package.

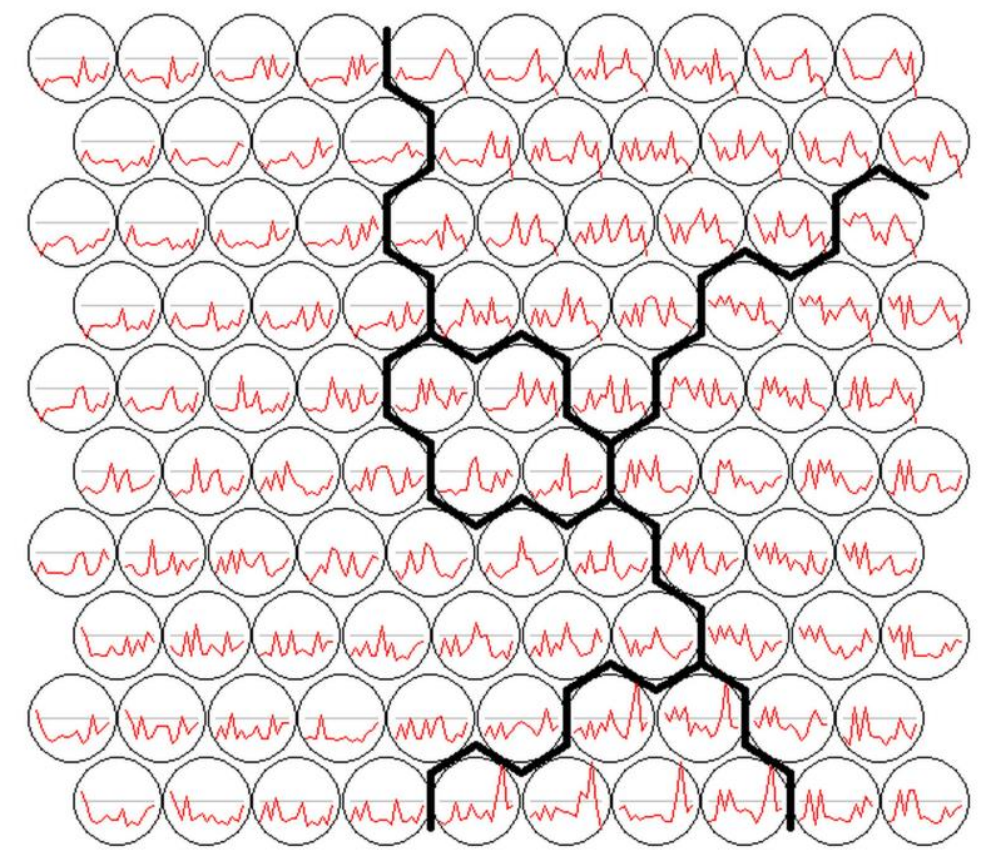

Fig. 5. Codes graph. Source own elaboration Source: own elaboration from AEF database.

Figure 6 shows the case counts for each node. The group represented to the left is the most numerous and there are also some nodes marked with an asterisk, which implies that no case has been located within those nodes. Additionally, in Figure 5, the five clusters obtained through the application of SOM to the database of entrepreneurs in Andalusia are presented again, although more simply. 


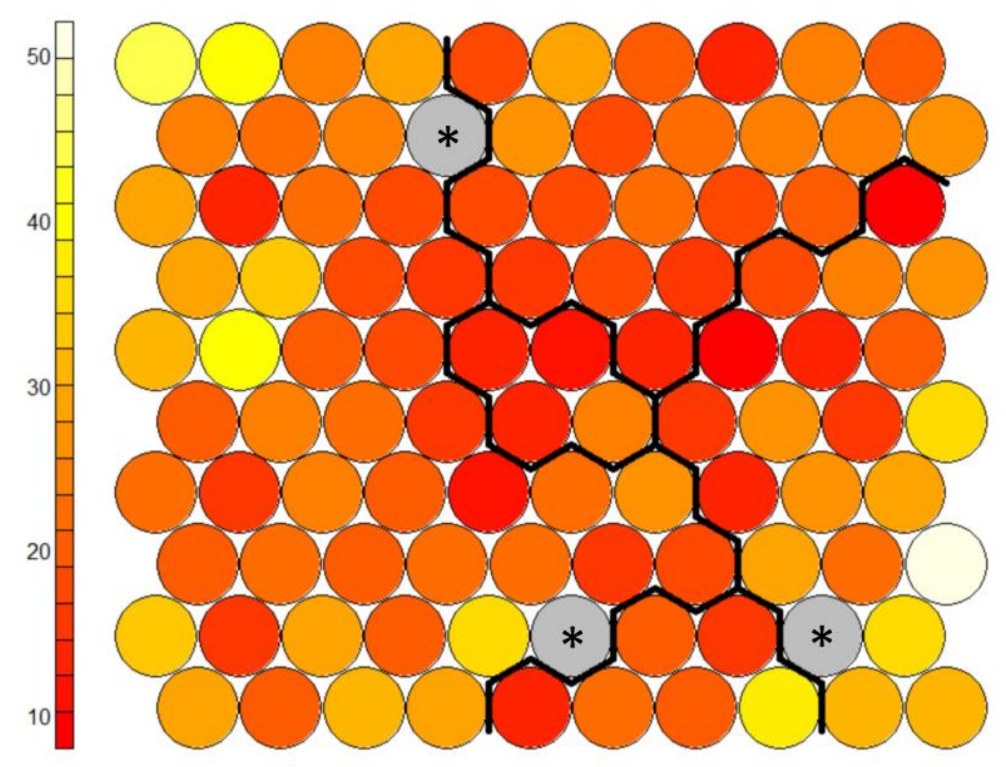

Fig. 6. Case counts per node. Source own elaboration Source: own elaboration from AEF database

Grosso modo, it is observed that the clusters have the following characteristics which would be taken into account in order to predict the probability of success:

- Cluster 1: entrepreneurs without employment plan or impact on the local productive sector and accommodation.

- Cluster 2: entrepreneurs with an employment plan.

- Cluster 3: entrepreneurs who have a development plan, do not have an employment plan, but have an impact on the local productive sector.

- Cluster 4: entrepreneurs without an employment plan or incidence in the local productive sector and with accommodation (office) provided.

- Cluster 5: entrepreneurs without an employment plan, with an impact on the local productive sector and without accommodation (office) provided.

Table 2. Summary of descriptive statistics of the clusters

\begin{tabular}{|l|c|c|c|c|c|c|}
\hline & $\begin{array}{c}\text { Indefinite workers } \\
\text { (average) }\end{array}$ & $\begin{array}{c}\text { Temporary } \\
\text { workers (average) }\end{array}$ & $\begin{array}{c}\text { Mean gross } \\
\text { sales }\end{array}$ & $\begin{array}{c}\text { Gross sales/ } \\
\text { employees }\end{array}$ & $\begin{array}{c}\text { Relative financial } \\
\text { profitability }\end{array}$ & $\begin{array}{c}\text { Total } \\
\text { investments }\end{array}$ \\
\hline Cluster 1 & 1.97 & 2.31 & $99,925 €$ & $43,932 €$ & $27.20 \%$ & $24,499 €$ \\
\hline Cluster 2 & 2.93 & 3.05 & $120,655 €$ & $46,393 €$ & $72.80 \%$ & $15,548 €$ \\
\hline Cluster 3 & 2.55 & 1.73 & $90,536 €$ & $73,136 €$ & $18.90 \%$ & $21,591 €$ \\
\hline Cluster 4 & 1.65 & 1.77 & $69,241 €$ & $42,011 €$ & $34.80 \%$ & $9,642 €$ \\
\hline Cluster 5 & n/a & n/a & n/a & n/a & n/a & n/a \\
\hline
\end{tabular}

Source: own elaboration from AEF database. 


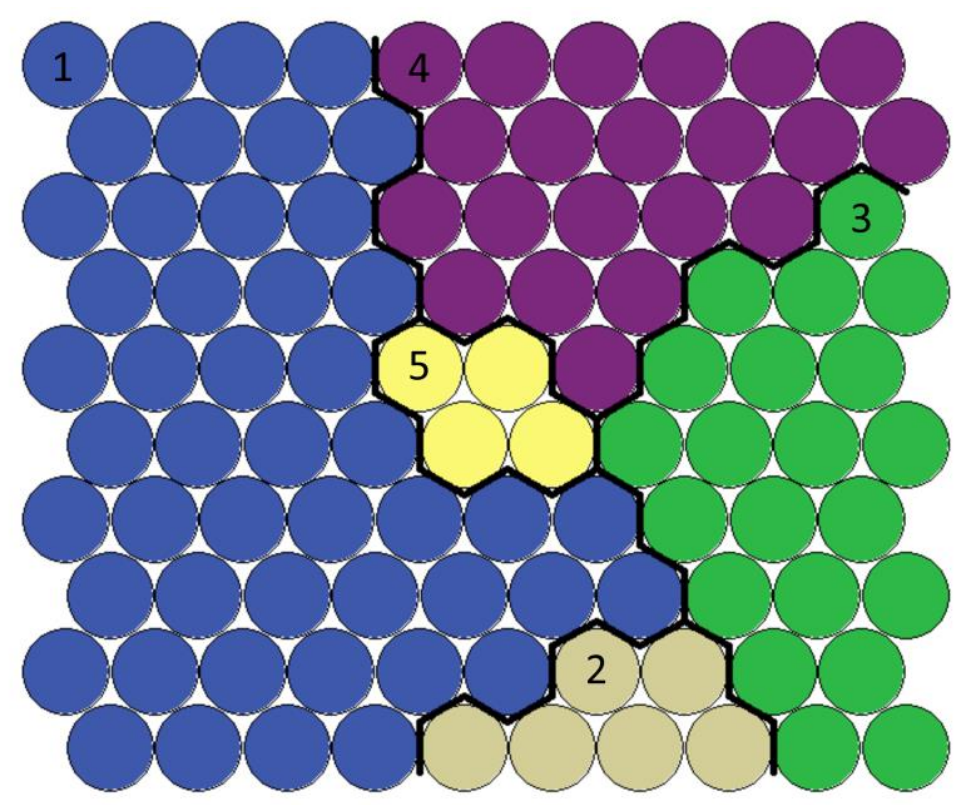

Fig. 7. Clusters obtained by SOM networks. Source own elaboration Source: own elaboration from AEF database.

Table 2 specifies the behavior of each of the clusters concerning the dependent variables considered to validate the classification obtained (note that the data from cluster 5 are not sufficient to assess success since most of these cases have not survived two years).

When performing the statistical tests to verify that there is an association with a "success" variable (obtained from the previous dependent variables) in each of the clusters, it is observed that it can be accepted that there are significant differences between the obtained clusters (Table 3).

Since it is possible to use an artificial neural network to classify the data appropiately for the present line of research, likely, it will also be possible to train another neural network (for example, a MLP) to be able to estimate the probability of success of each individual that is going to start a business entrepreneurship project.

Table 3. Pearson's chi-squared test for association

\begin{tabular}{|l|l|l|l|}
\hline & Value & df & $\begin{array}{l}\text { Asymp. Sig. } \\
\text { (2-sided) }\end{array}$ \\
\hline Pearson chi-square & 50.146 & 12 & $<0.0005$ \\
\hline Likelihood ratio & 48.708 & 12 & $<0.0005$ \\
\hline Linear-by-linear association & 0.932 & 1 & 0.334 \\
\hline N of valid cases & 2,210 & & \\
\hline
\end{tabular}

Source: own elaboration from AEF database.

The first MLP was trained by data partition and with SPSS software. In this case, the neural network classified the cases according to Table 4 . 
ENTREPRENEURSHIP AND SUSTAINABILITY ISSUES

ISSN 2345-0282 (online) http://jssidoi.org/jesi/

2020 Volume 8 Number 2 (December)

http://doi.org/10.9770/jesi.2020.8.2(40)

Make your research more visible, join the Twitter account of ENTREPRENEURSHIP AND SUSTAINABILITY ISSUES: @Entrepr69728810

Table 4. Classification of cases by MLP

\begin{tabular}{|l|l|l|l|l|}
\hline Classification / MLP & \multicolumn{1}{|c|}{ Success } & \multicolumn{1}{|c|}{ Survival } & Failure & Total PML \\
\hline Success & 123 & 6 & 1 & 130 \\
\hline Survival & 2 & 985 & 9 & 996 \\
\hline Failure & 0 & 6 & 1047 & 1053 \\
\hline Total cases & 125 & 997 & 1057 & \\
\hline
\end{tabular}

Source: own elaboration from AEF database.

With the repetition of training several times, it was possible to get the trained network to succeed in its forecast on the set of tests $98.4 \%$ of times.

The next MLP training was obtained with a model of stability improvement by self-aggregation aggregation and through IBM modeler (see details in Table 5).

According to the resulting models, the most relevant variables are the sector; the probability of survival of the environment; the number of employees; the region; the number of support services. Note that during the orientation process you can act by modifying the project to choose the most convenient values in most of the variables listed above. I Variables such as the probability of survival indicate the importance of choosing the location for the first implementation of entrepreneurs. Others like the number of entrepreneurship support services received that detail the interest or involvement of the new entrepreneur in the project, clearly influences the venture's probability of success, not so much individually but as a combination of factors, which is one of the justifications for using SOM analysis and neural networks as a methodology for prediction of success.

Table 5. Pearson's chi-squared test for association.

\begin{tabular}{|l|l|r|}
\hline \multicolumn{2}{|c|}{ Model Summary } \\
\hline \multirow{4}{*}{ Training } & Cross Entropy Error & 479,809 \\
\cline { 2 - 3 } & \% of incorrect forecasts & $8 \%$ \\
\cline { 2 - 3 } & Stop rule used & 1 step \\
\cline { 2 - 3 } & & $\begin{array}{l}\text { consecutive without } \\
\text { decreasing the error a }\end{array}$ \\
\cline { 2 - 3 } Test & Preparation time & $00: 03,1$ \\
\cline { 2 - 3 } & Cross Entropy Error & 175,204 \\
\hline Variable dependent: RNA_Éxito & $5,80 \%$ \\
\hline \multicolumn{2}{|l|}{ a. Error calculations are based on the test sample } \\
\hline
\end{tabular}

Source: own elaboration from AEF database.

\section{Conclusions}

Entrepreneurship is not only essential to reduce unemployment, but it is also critical to improve the competitiveness of the economy (Spulber, 2014; Mamun et al., 2017). In this context of global Covid-19 crisis in which the most efficient and effective mechanisms for economic recovery through entrepreneurship are required, this paper aimed to clarify if it is possible to support entrepreneurs by knowing a priori the probability of success of a business project based on the rest of the variables that affect the entrepreneur and his/her environment. A 


\section{ENTREPRENEURSHIP AND SUSTAINABILITY ISSUES}

ISSN 2345-0282 (online) http://jssidoi.org/jesi/

2020 Volume 8 Number 2 (December)

http://doi.org/10.9770/jesi.2020.8.2(40)

Make your research more visible, join the Twitter account of ENTREPRENEURSHIP AND SUSTAINABILITY ISSUES: @Entrepr69728810

technique based on artificial intelligence is adapted, by using self-organizing maps and a multilayer perceptron could make it possible.

After analyzing the context of the economic crisis in the first semester, considering differences of the current crisis concerning that of 2008, it has been observed that the role of the state has more weight and must take into account those most affected (micro, small and medium-size business). The opportunities perceived in the past financial crisis did not recover until after four years in most countries, except in those where the degree of government support and policies, financing for entrepreneurs and government programs were taken into account. The vast amount of historical information can no longer be wasted and we must use the new artificial intelligence techniques, avoiding general recipes for training and institutional support and being able to reconstitute the perceived opportunities of future entrepreneurs and, therefore, rebuilding the economy.

As previously cited, a replicable entrepreneurial success prediction model has been built today, based on two MLP and SOM techniques that have a hight capacity to take advantage of all this volume of historical information that is available on entrepreneurs. MLPs usually fit the data very well, but this is not proof that the model serves to predict in new situations (by overtraining). Therefore, it has been studied whether the data were likely to be grouped intrinsically and if this classification was related to survival and business success.

In the graph of SOM distances obtained, some differentiated zones can be observed. Nodes with a massive distance show highly differentiated cases and, therefore, will be more likely to belong to different groups, which behave differently in any attempt to predict success. Five groups of nodes were determined by the SOM trained, and the characteristics of the different groups revealed significant differences among them, in terms of the probability of failure (not survival), survival or success.

The differences in the probability of success among these homogeneous clusters seemed to be even independent of the definition chosen for this explained variable. If the explanatory variables are modified, the probability of success is affected. This is especially interesting if we consider simultaneously those variables that can be controlled from the point of view of the institutions that support entrepreneurs (assistance or accommodation, among others) as well as those variables linked to the environment where the project is to be located (one can study, for example, which location maximizes the future viability of the business project).

When developing the SOM, the variables that have been shown to affect more the prediction of the model are the following that there are significant differences in the five groups obtained at a $95 \%$ level of confidence:

- Environment: local productive; employment plan; type of business accommodation; financial profitability of the environment; supporting services; economic indicators of the environment.

- $\quad$ Entrepreneur and project: activity of the company; investment; financing; educational level; legal form; employees.

To achieve the most motivating results of the study (taking advantage of the possibilities of artificial neural networks), once the SOM groups have been obtained, a multilayer perceptron was designed with the entrepreneur variables and trained with the available data set. It helped the training to incorporate the "group" variable obtained by the SOM. This allowed us to model and make predictions about the probability of success of an entrepreneur, as well as to know the variations of probabilities when changing the values of the initial variables. The more influential variables became: the sector; the probability of survival of the environment; the number of employees; the province; and the number of support services. 


\section{ENTREPRENEURSHIP AND SUSTAINABILITY ISSUES}

ISSN 2345-0282 (online) http://jssidoi.org/jesi/

2020 Volume 8 Number 2 (December)

http://doi.org/10.9770/jesi.2020.8.2(40)

Make your research more visible, join the Twitter account of ENTREPRENEURSHIP AND SUSTAINABILITY ISSUES: @Entrepr69728810

We hold that it makes sense to apply this type of methodology in practice when sufficient data are available (in number and reliability) to train a neural network properly. Today, public support systems for entrepreneurs have abundant sets of adequate data; however, they do not usually take advantage of them, beyond the use that each support service worker makes individually (and, in many cases, subconscious). As has been seen in the present investigation, there are factors that condition the success of entrepreneurs and that can be modulated through the support service itself or the modification of the business project in question. Besides, it can be deduced that there is no single recipe for success, but that entrepreneurs can be classified according to their characteristics and their projects so that belonging to one of the groups implies that certain actions in the counseling will have a different effect of what is expected in cases belonging to other groups.

If we attend to this set of recommendations, to the question ways to support entrepreneurship after the covid-19 crisis, it is possible to perform as a joint and coordinated system that includes analyzes and decides according to the following considerations:

- The combination of variables that the entrepreneur brings in.

- The optimal business segment to carry out his activity.

- The most favorable values of the investment budget.

- The training, capacities and technical characteristics that the entrepreneur must have or promote.

- The type of service we must provide you throughout your career.

- The support institution will define all these factors through the system of maximizing the expected benefit built on the basis of the neural network system explained in this study.

In conclusion, an unsupervised artificial neural network generated groups compatible with an eventual classification of entrepreneurs according to their level of success. Hence, there is non-subjective information in the data that determines the probability of business success. Thanks to the SOM technique, it has been possible to establish groups where it is easy to classify the cases of entrepreneurship a priori and which seem to behave in a significantly different way from the rest concerning the variables that are often used to measure business success. Besides, by using other quite reasonable estimation techniques like MLP, it is possible to obtain really good fits. In fact, the network was trained several times and all of them came out something similar, which supports the reliability of the model. Therefore, it is realistic to know in each case the influence of relevant factors related to the advice for increasing the chances of success of the entrepreneurs. This final model will be the basis for implementing an artificial intelligence system to improve the orientation of future entrepreneurs.

As for recommendations for further research, a functional relationship could be obtained in any other region, between the initial variables (which describe the characteristics of the entrepreneur, the project, the environment, as well as the type of public service received) and the final variables of success (success, survival, failure, economic and financial indicators of performance, etc.). In a same technological application, it would be possible to implement the different aspects developed in the research: (i) to collect and process the necessary information for the estimations; (ii) training the specific neural network for the specific socio-economic situation to be improved; (iii) use of the forecasts to make the most appropriate recommendations to each individual; (iv) use the final information obtained to improve the estimates in subsequent counseling processes.

In short, we must be aware that we are heading to a time when human decisions can be based on the information that lies in extensive databases that cannot be accessed by the human brain (as in Stukal et al. 2019). The right use of artificial intelligence can allow us to optimize the chances of success in the implementation of solutions for the most significant economic and social problems of our days. 


\section{ENTREPRENEURSHIP AND SUSTAINABILITY ISSUES}

ISSN 2345-0282 (online) http://jssidoi.org/jesi/

2020 Volume 8 Number 2 (December)

http://doi.org/10.9770/jesi.2020.8.2(40)

Make your research more visible, join the Twitter account of ENTREPRENEURSHIP AND SUSTAINABILITY ISSUES: @Entrepr69728810

\section{References}

Al-Jubari, I. 2019. College students' entrepreneurial intention: Testing an integrated model of SDT and TPB, SAGE Open, (92) https://doi.org/10.1177/2158244019853467

Álvarez, S. A.; Busenitz, L. W. 2001. The entrepreneurship of resource-based theory, Journal of Management, 27, 755-775.

Anzola, S. 1997. De la idea a tu empresa. Una guía para emprendedores, México, Ed. Limusa.

Aparanji, V. M.; Wali, U. V.; Aparna, R. 2018. Automated path search and optimization of robotic motion using hybrid ART-SOM neural networks. In: Proceedings of International Conference on Recent Advancement on Computer and Communication, Singapore, Springer, 415-423.

Azizi, M.; Mahmoudi, R. 2019. Learning outcomes of entrepreneurship education: Entrepreneurship education for knowing, doing, being, and living together, Journal of Education for Business, (943), 148-156. https://doi.org/10.1080/08832323.2018.1502139

Bárcena, A. 2020. Coyuntura, escenarios y proyecciones hacia 2030 ante la presente crisis de Covid-19. Santiago de Chile: CEPAL.

Baron, R. A. 2000. Psychological perspectives on entrepreneurship cognitive and social factors in entrepreneurs' success, Current Directions in Psychological Science, 9, 15-18.

Bruneel, J.; Spithoven, A.; Clarysse, B. 2017. Interorganizational trust and technology complexity: Evidence for new technology-based firms, Journal of Small Business Management, (55S1), 256-274.

Chaves Maza, M., Fedriani, E. M., \& Ordaz Sanz, J. A. (2018). Factores relevantes para optimizar los servicios públicos de apoyo a los emprendedores y la tasa de supervivencia de las empresas. Innovar, 28(69), 9-24.

Covin, J. G.; Slevin, D. P. 1991. A conceptual model of entrepreneurship as firm behavior, Entrepreneurship Theory and Practice, (161), 7-25. Retrieved from: https://ssrn.com/abstract=1504448

Cuevas-Vargas, H.; Parga-Montoya, N.; Fernández-Escobedo, R. 2019. Effects of entrepreneurial orientation on business performance: The mediating role of customer satisfaction $-\mathrm{A}$ formative-reflective model analysis, SAGE Open, (92). https://doi.org/10.1177/2158244019859088

Curiel-Marín, E.; Passoni, L. I.; Olmedo-Moreno, E. M.; Fernández-Cano, A. 2018. Los mapas autoorganizados para la evaluación de la investigación de tesis doctorales: el caso de la didáctica de las Ciencias Sociales en España, Relieve, (241) https://doi.org/10.7203/relieve.24.1.12345

Dai, R., Hu, J., \& Zhang, X. 2020. The Impact of Coronavirus on China's SMEs: Findings from the Enterprise.

DiGiacomo, A. 2020. La gobernabilidad en tiempos del COVID 19: una mirada desde Europa y Sudamérica. Journal de Ciencias Sociales. Douglas, T. J.; Judge, W. Q. 2001. Total quality management implementation and competitive advantage: the role of structural control and exploration, Academy of Management Journal, 44, 158-169.

Filella, J. 1997. La personalidad empresarial, Iniciativa Emprendedora y Empresa Familiar, 6, 13-19.

George, G.; Bock, A. J. 2011. The business model in practice and its implications for entrepreneurship research, Entrepreneurship Theory and Practice, (351), 83-111.

Global Entrepreneurship Research Association (GEM) 2020. Data base https://www.gemconsortium.org/data . London Business School,

Gibb, A. A. 1993. Key factors in the design of policy support for the small and medium enterprise (SME) development process: an overview, Entrepreneurship \& Regional Development, 5, 1-24.

Moskvina, J. 2013. Social enterprises as a tool of social and economic policy, Entrepreneurship and Sustainability Issues 1(1): 


\section{ENTREPRENEURSHIP AND SUSTAINABILITY ISSUES}

ISSN 2345-0282 (online) http://jssidoi.org/jesi/

2020 Volume 8 Number 2 (December)

http://doi.org/10.9770/jesi.2020.8.2(40)

Make your research more visible, join the Twitter account of ENTREPRENEURSHIP AND SUSTAINABILITY ISSUES: @Entrepr69728810

45-54. http://dx.doi.org/10.9770/jesi.2013.1.1(5)

Hawkins, K. L.; Turla, P. A. 1987. Compruebe sus dotes de emprendedor, Madrid, Ediciones Deusto.

Ireland, R. D.; Covin, J. G.; Kuratko, D. F. 2009. Conceptualizing corporate entrepreneurship strategy, Entrepreneurship Theory and Practice, 33, 19-46. http://dx.doi.org/10.1111/j.1540-6520.2008.00279.x

Lamedica, R., Prudenzi, A., Sforna, M., Caciotta, M., \& Cencellli, V. O. (1996). A neural network based technique for short-term forecasting of anomalous load periods. IEEE Transactions on Power Systems, 11(4), 1749-1756. https://doi.org/10.1109/59.544638

Larrea, I.; Ayerbe, M. 1996. Jóvenes directivos y actitud empresaria, Bilbao, Universidad de Deusto, Deustuko Unibertsitatea.

Mamun, A.; Che Nawi, N. B.; Mohiuddin, M.; Shamsudin, S. F. F. B.; Fazal, S. A. 2017. Entrepreneurial intention and startup preparation: A study among business students in Malaysia, Journal of Education for Business, (926), 296-314. https://doi.org/10.1080/08832323.2017.1365682

Mangiameli, P., Chen, S. K., \& West, D. (1996). A comparison of SOM neural network and hierarchical clustering methods. European Journal of Operational Research, 93(2), 402-417. https://doi.org/10.1016/0377-2217(96)00038-0

Mitchelmore, S. and Rowley, J. (2010). Entrepreneurial competencies: a literature review and development agenda, International Journal of Entrepreneurial Behaviour \& Re-search, 16, pp. 92-111.

Morris, M.; Schindehutte, M.; Allen, J. 2005. The entrepreneur's business model: toward a unified perspective, Journal of Business Research, (586), 726-735.

Peteraf, M. A. 1993. The cornerstones of competitive advantage: A resource-based view, Strategic Management Journal, 14, 179-191. Rock, A. 1987. Strategy vs. tactics from a venture capitalist, Harvard Business Review, 65, 63-67.

Rothe, C.; Schunk, M.; Sothmann, P.; Bretzel, G.; Froeschl, G.; Wallrauch, C.; \& Seilmaier, M. 2020. Transmission of 2019-nCoV infection from an asymptomatic contact in Germany. New England Journal of Medicine, (38210), 970-971.

Sandberg, W.; Robinson, R.; Pearce, J. 2001. Why small businesses need a strategic plan, Business \& Economic Review, 48, 12-15.

Schnabl, P.A. 2010. The theory of the firm: microeconomics with endogenous entrepreneurs, firms, markets, and organizations. In: American Library Association Choice, http://dx.doi.org/10.1017/CBO9780511819902

Sörensson, A.; Bogren, M. 2019. Organizing an entrepreneurial learning programme: The role of people, process and place, Industry and Higher Education, doi: https://doi.org/10.1177/0950422219857598

Spulber, D. F. 2014. The innovative entrepreneur, Cambridge, Cambridge University Press.

Stewart Jr., W. H.; Roth, P. L. 2001. Risk propensity differences between entrepreneurs and managers: a meta-analytic review, Journal of Applied Psychology, 86, 145-153.

Stukal, D.; Sanovich, S.; Tucker, J. A.; Bonneau, R. 2019. For whom the bot tolls: A neural networks approach to measuring political orientation of twitter bots in Russia, SAGE Open, (92). https://doi.org/10.1177/2158244019827715

Timmons, J. A.; Spinelli, S. 1994. New venture creation: Entrepreneurship for the 21st century, Boston, Irwin.

Urban, U. 2018. The influence of the regulatory, normative and cognitive institutions on entrepreneurial orientation in South Africa, The International Journal of Entrepreneurship and Innovation, (203), 182-193. https://doi.org/10.1177/1465750318796721

Wiklund, J.; Shepherd, D. 2005. Entrepreneurial orientation and small business performance: A configurational approach, Journal of Business Venturing, 20, 71-91. 


\section{ENTREPRENEURSHIP AND SUSTAINABILITY ISSUES}

ISSN 2345-0282 (online) http://jssidoi.org/jesi/

2020 Volume 8 Number 2 (December)

http://doi.org/10.9770/jesi.2020.8.2(40)

Make your research more visible, join the Twitter account of ENTREPRENEURSHIP AND SUSTAINABILITY ISSUES: @Entrepr69728810

\section{Acknowledgements}

This research was supported by Pablo de Olavide University (Spain) and data was collected from Andalucia Emprende

Fundation that participates in the European Erasmus for Young Entrepreneurs project through the project called MOVE YE.

\section{Manuel CHAVES-MAZA}

ORCID ID: https://orcid.org/0000-0003-2420-8378

Eugenio M. FEDRIANI MARTEL

ORCID ID: https://orcid.org/0000-0002-1707-3308

Copyright (C) 2020 by author(s) and VsI Entrepreneurship and Sustainability Center

This work is licensed under the Creative Commons Attribution International License (CC BY).

http://creativecommons.org/licenses/by/4.0/

(c) (i) Open Access 